今回のシンポジウムの主題となった “気管食 道科における診断の進歩” は, 本学会の最近の 動向を総括するとともに, 診断面の今後の発展 を期するための企画であったと考えられる。医 学のどの領域についてもいえることであるが, 診断面の進歩を支えるのはまず機器の発達と応 用手技の展開であろう。しかしこのような“八 一ド”の面の進歩に対し, 機器を用い, それに よってえられたデー夕を判断するのはあくまで 医師であり，その判断や運用面の進歩すなわち “ソフト”の進歩こそ学問の進歩につながるもの であることをはじめに強調しておきたい。

さてシンポジウムの個々のテーマは便宜的 に, 画像診断と視診, 機能検查, 特殊な病態の 診断, 総合的診断方式に分けられ, さらに最初 の 2 つは 2 名の演者に分担願うこととした。以 下,個々のテーマについて簡単にふれてみたい。

\section{1. 画像診断と視診}

画像診断として現在最も重要なものは放射線 診断であろう。とくに最近脚光を浴びている CT と MRI の問題について,この方面の経験の 深い多田助教授に報告を打願いした。CTにつ いてはとくに喉頭癌の進展の診断が中心課題と なり, 一方 MRI では食道癌の診断への応用が 論じられた。文献的にみると, CT の応用範囲と して,このほか反回神経麻痺の原因診断や異物 の診断などへの適用がすでに報告されている。 CT の普及度はきわめて高いだけに，今後ます ますその実用価值が高まっていくことが予想さ れた。MRIについてはまだ気管食道科への応用 の初期段階にあり今後どのような可能性がある のかを見極めていく必要があると感じられた。

歴史的にみても気管食道科の発展は, 内視鏡 の開発とその技術の進歩とともに歩んできたと

*東京:京大学医学部音声言語医学研究施設

\section{司会者 ${ }^{*}$ 廣 瀬肇} イバースコープの導入であり，今日では，その 使用がすでに定着したものと考えられる。福田 講師は内視鏡的診断および治療の第一人者であ るが，今回はとくに喉頭と食道入口部の検査に ついて報告した。すなわち，各種の実用機器を 概観したうえで, 声帯振動のストロボビデオグ ラフィや食道入口部観察の新しい方式について 述べ，さらに声帯に受動的な振動を与えてその 観察結果から声帯の物性の異常を推定するとい うユニークな試みにも言及して治療方針の決定 への有用性を強調した。

\title{
2. 気道・食道の機能検査
}

気道・食道はいずれも管腔臓器であり，その 通過性は臓器機能としてきわめて重要である。 とくに気道は呼吸通路としての意義があり,こ れと関連して従来から気道狭窄の客観的評価に 主眼をおいた検査が開発されてきた。今回，中 島教授は，抵抗負荷テストや $\mathrm{He}-\mathrm{O}_{2} \mathrm{FV}$ 曲線の 結果を検討することにより，かなり軽度の上気 道狭窄まで検出できる可能性について報告し た。臨床的に狭窄の程度を数量化して表示する ことには大きな意義があり, 今後こうした検査 法が普及し，さらに実用的になっていくことが 望まれる。

一方, 気道・食道の内圧検査について, 小宮 山講師は豊富な経験からとくに嚥下圧の計測の 意義や, 音声医学領域における声門下圧および 口腔内圧測定の実用性を論じた。嚥下圧の測定 を咽頭から食道にかけてのいろいろなレベルで 実施することにより，誤嚥の性質を分析的に記 載し鑑別診断に応用できることはきわめて有意 義である。声門下圧の測定は発声効率の算定に 必要であり, 従来からその意義が指摘されてい たところである。最近では圧トランスデューサ が小型化し，比較的容易に臨床例に適用できる 
ようになっており，正常例についてのさらに詳 細なデータの積み重ねに加えて, 病態生理の研 究の面にも内圧測定を普及させていく努力が必 要であると考えられた。

\section{3. 喉頭運動障害の診断}

特殊な病態の診断として, 今回のシンポジウ ムでは喉頭運動障害の問題をとりあげ，岩村部 長に，とくに反回神経麻痺の診断と予後判定に ついての報告をお願いした。ここでは主として 自然治癒の可能性に関連する要因が検討された が，必ずしも従来の教科書的な考えと一致しな い結果がえられた点は興味深いと思われた。あ えて問題点をあげるとすれば，筋電図検査の意 味づけに関する論議の中で, 発症後のどの時点 で筋電図検査が施行されたかについての論及が 割愛されており，これは今後の検討課題となり うると考えられた。

\section{4. 喉頭運動の特殊観察法など}

シンポジウムの最後に，吉田助教授により特 別発言があり，喉頭運動の特殊観察法として発 声時声帯のストロボビデオグラフィについて報 告され，さらに筋電図とX線ビデオを組合わせ た嚥下動態観察方式が紹介された。これらの方 法は技術的な制約もあって，各施設で簡単には 実施しにくい面もあるが，総合的診断法として の威力には特筆すべきものがあると思われた。 今回のシンポジウムを通じて診断面の進歩が 今後もさらに続いていくであろうという感を深 くしたのは事実である。しかし，臨床的見地か らすれば，診断の進歩はあくまで治療の進歩に 直結していくべきものであると考えられる。こ の両面における進歩を促進するように，本学会 全体としての努力が稔っていくことをあらため て念願したい。 